$\overline{\text { 綜 説 }}$

\title{
ブドウ糖非醱酵グラム陰性桿菌感染症
}

— Acinetobacter calcoaceticusによる感染症

\author{
順天堂大学医学部臨床病理学教室 \\ 猪狩淳
}

はじめに

近年, 各種化学療法剤の開発和よび化学療法の 発達は感染症に対する治療法を飛躍的に向上させ たが，一方，原因菌にも大きな変化をもたらし， 感染症の様相に変化を生じてきていることは周知 のことである. 薬剤耐性菌の出現, 菌交代症の問 題とともに，常用抗生剤に自然耐性を示すことの 多い緑膿菌や変形菌の増加が新らたな問題として とりあげられた。これら菌種による感染症の増加 は, これらのもつ薬剤感受性の特徵に加兄て, 宿 主側の諸因子の介在も感染症の变貌の要因として 考えなければならない, 悪性腫瘍, 白血病, 免疫 不全症などの感染抵抗性の減弱をきたしやすい病 態, 大手術, 放射線療法, ステロイド阂や免疫抑 制剂の使用頻度の増大は従来非病原菌, 弱毒菌々 いわれた細菌にも易感染性の機会を増加させた。 とくに，多くの抗生剂に自然耐性のある，いわゆ る opportunistic pathogens として注目されてい る Klebsiella, Enterobacter, Serratia などの腸内 細菌と Pseudomonas 属, Acinetobacter 属など のブドウ糖非醗酵グラム陰性桿菌などが菌交代 症, opportunistic infection として難治感染症を ひき抏こしている. 以下，これらのらち，Acinetobacter 感染症について述べる。

\section{Acinetobacter について}

Acinetobacter は広く自然界に分布し, 食物, 土壌や水中からしばしば分離され, 健康人からも 分離されることがある。

本菌はブドウ 糖非醗酵性のグラム陰性短桿菌 で, チトクロームオキシダーゼ陰性, カタラーゼ 陽性, 非運動性でブドウ糖を酸化的に分解するも
のと非分解性のものとがある. 以前は糖を分解す るものを Hellera vaginicola, Bacterium anitratum, Achromobacter anitratus などと呼び，糖を 分解しないものを Mima polymorpha, Moraxella 1woffi などと呼んだ。1971年 International Committee on Systematic Bacteriology の Moraxella 小委員会は, Acinetobacter 属の菌種は Acinetobacter calcoaceticus (以下 Ac. calcoaceticus) の みとし, 糖分解性の Ac. anitratus と非分解性の Ac. Iwoffi の両者を含ませることを提案した ${ }^{1)}$. Bergey's Manual 第8版 (1974年) には Neisseria 科にあり, Acinetobacter 属には Species として Ac. calcoaceticus 1 菌種が記載された。しかし， この分類に異論を唱える学者もいる. 最近, 本 菌による感染症が報告されてきて和り，多くの薬 剂に耐性であることが指摘されている2

\section{Ac. calcoaceticus の感染例とその臨床的}

\section{背景}

昭和51年 10 月より昭和 52 年 5 月をでに順天堂大 学病院中検で, Ac. calcoaceticus の分離された 臨床材料をみると, 疢・咽頭粘液が最も多く, 次 いで尿，創傷 (膿)，胆汁の順になり，泀とんどの 分離株は他菌種との mixed culture で, pure culture として分離されたものは数株にすぎない.な 扮分離例は耳漏, 胵分泌物を除けばすべて入院患 者である (Table 1).

分離例の基礎疾患をみると, 臨床材料により幾 分異なるが, 慢性疾患, 悪性腫瘍, 手術例, 慢性 感染症などであり, 喀痰より分離された22例につ いてしらべた成績では, 慢性肺疾患 8 例, 他菌種 による気管支肺炎 5 例, 肺悪性腫瘍 5 例, 脳血管 
Table 1. Sourses of Ac. calcoaceticus

\begin{tabular}{|c|c|c|c|}
\hline Sources & \begin{tabular}{|l|} 
No. of \\
strains \\
isolated
\end{tabular} & $\begin{array}{l}\text { Mixed } \\
\text { cultures }\end{array}$ & $\begin{array}{l}\text { No. of } \\
\text { patients }\end{array}$ \\
\hline \multirow{2}{*}{$\begin{array}{r}\text { Respiratory tract Sputum } \\
\text { Throat }\end{array}$} & 56 & 53 & 33 \\
\hline & 15 & 15 & 13 \\
\hline \multirow{2}{*}{ Urine $\begin{aligned} & \geqq 10^{5} / \mathrm{ml} \\
& <10^{5} / \mathrm{ml}\end{aligned}$} & 7 & 6 & \multirow{2}{*}{11} \\
\hline & 9 & $8\}$ & \\
\hline Bile & 6 & 4 & 6 \\
\hline Wound & 8 & 3 & 8 \\
\hline Blood & 1 & 1 & 1 \\
\hline Miscellaneous & & & \\
\hline Ear & 2 & 2 & 2 \\
\hline Vagina & 2 & 2 & 2 \\
\hline Ascites & 1 & 1 & 1 \\
\hline Autopsy tissue & 1 & 1 & 1 \\
\hline Total & 108 & 96 & 78 \\
\hline
\end{tabular}

(1976. 10. 1-1977. 5. 31)

Table 2. Clinical Backgrounds of 22 Patients with Positive Ac. calcoaceticus (isolatedfr om sputum).

\begin{tabular}{lr}
\hline Factorsinfluencing general & \\
resistans & 2 \\
Postoperative & 2 \\
Diabetes mellitus & 1 \\
Renal failure & 5 \\
Steroid treatment & 5 \\
Anticancer chemotherapy & 4 \\
Radiation treatment & 16 \\
Antibiotic treatment & 2 \\
Instrumentation & 1 \\
Tracheotomy & \\
Bronchoscopy &
\end{tabular}

障害 4 例で，それに糖尿病，腎不全を合併した例 がそれぞれ 2 例と 1 例であつた。

さらに上記喀痰分離例について感染を若起する 宿主側の因子をしらべると，Table 2 に示すよう なるのであつた。とくに注目すべきことは本菌分 離前にすでに化学療法剤が使用されていた例が 16 例 $(70 \%)$ あつたことである．合成ペニシリン剂 が 8 例，セファロスポリン剂が 7 例で，ちち 5 例 が両者を使用しており，その他に nalidixic acid, colistin, gentamicin 使用例が 1 例ずつあつた. な招 Ac. calcoaceticus が検出される以前に他
菌種が検出されて括り, 治療中に本菌が検出され た。

尿分離例では排尿障害があり尿道留置カテーテ ルを留置し，慢性下部尿路感染症を併発している 例に，本菌が一時的にあるいは連続して他菌と mixed culture の形で分離される例が多かつた。

しかも，長期抗生剂投与例に検出される頻度が高 い.

本菌が単独で, 純培養状に分離された例は胆汁 分離の 2 例之創傷分離の 3 例であつた. 胆汁分離 例は 2 例とも胆道癌の末期例で抗生剂投与, 抗癌 剂投与, ${ }^{60} \mathrm{Co}$ 照射例であり，創傷分離例は手術 後の術創感染例である.

Ac. calcoaceticus による各種感染症に関する 報告は多く, 敗血症, 心内膜炎, 髄膜炎, 脳膿 瘍, 肺炎, 肺膿瘍, 上気道炎, 膿胸, 尿路感染 症, 腹腔内膿瘍, 骨盤内膿瘍, 化膿性関節炎, 骨 髄炎, 創傷感染, 結膜炎, 静脈炎などが報告され ている ${ }^{2)}$. 一般に本菌に上る感染例は入院患者に 多く, 乙か子高秢者, 慢性疾患, 重症急性疾患, 大手術後, 気管内チューブ, 静脈カテーテル，尿 道留置カテーテルなどの施行例, 抗生剂投与例な ぞの感染防御機構の低下した例にみられるといわ れている.著者らの例では, 前述した 2 例の胆汁 分離例（胆道感染）と 3 例の術創感染例は本菌が 感染の原因菌として否定できないが，喀痰や尿分 離例では本菌の病原性は疑わしい。しかし，どの 例も重篤な基礎疾患をもち，抗生剂投与を受け， さらにステロイド風や，抗癌剤の投与例があり， 放射線治療例もあり, 感染防御機構を低下せしめ る因子が関与している。

本菌が原因菌としての役割をどの程度もつかと いらことは諸家によつていろいろ論じられている

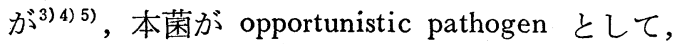
難治感染症を惹起する可能性があることには医ぼ 意見が一致している。

\section{3. 薬剂感受性について}

本菌の化学療法剤感受性については Table 3 に 示した. 各種臨床材料由来株について, 日本化学 療法学会標準法により最小発育濃度 (MIC) を 
Table 3. Susceptibility of Ac. calcoaceticus to Antibiotics

\begin{tabular}{|c|c|c|c|c|c|c|c|c|c|c|c|c|c|c|}
\hline & \multicolumn{14}{|c|}{$\operatorname{MIC}(\mu \mathrm{g} / \mathrm{ml})$} \\
\hline & $\leqq 0.1$ & 0.2 & 0.39 & 0.78 & 1.56 & 3.13 & 6.25 & 12.5 & 25 & 50 & 100 & 200 & 400 & $>400$ \\
\hline$\overline{\mathrm{AB}-\mathrm{PC}}$ & & & & & & & & & 13 & 32 & 3 & 1 & & 1 \\
\hline SB-PC & & & & & & & & & 4 & 15 & 51 & 3 & 5 & 1 \\
\hline CER & & & & & & & & & & & 3 & 16 & 30 & 1 \\
\hline CEZ & & & & & & & & & & & 2 & 3 & 3 & 90 \\
\hline KM & & & & & 23 & 33 & 4 & 2 & & & & 1 & & .1 \\
\hline GM & 1 & 3 & 21 & 51 & 21 & 4 & 8 & 2 & & & & 1 & & \\
\hline DKB & & & & 4 & 17 & 31 & 6 & 3 & 2 & & & & & 1 \\
\hline AMK & & & & 1 & 19 & 27 & 14 & 2 & & & & & & 1 \\
\hline EM & & & & & & 2 & 47 & 41 & 7 & & & & & 1 \\
\hline LCM & & & & & & & & & & 1 & & & & 49 \\
\hline CLDM & & & 1 & & & & 1 & & 1 & 16 & 28 & 35 & 10 & 6 \\
\hline & & 1 & & 20 & 45 & 40 & 5 & & & & 1 & 2 & & \\
\hline MINO & 110 & 24 & 1 & & & & & & & & & & & \\
\hline DOTC & 78 & 30 & 17 & 4 & 2 & 2 & & & 2 & & & & & \\
\hline $\mathrm{CP}$ & & & & & 1 & & & 3 & 2 & 8 & 44 & 49 & 5 & \\
\hline CL & & & & & 19 & 71 & 18 & 3 & & & & & 1 & \\
\hline $\mathrm{NA}$ & & & & & & 4 & 23 & 16 & 7 & & & & & \\
\hline $\mathrm{PA}$ & & & & & & & 1 & 10 & 48 & 32 & 7 & & & \\
\hline PPA & & & & & & & & 1 & 12 & 63 & 20 & 1 & & 1 \\
\hline
\end{tabular}

(1976. $1 \sim 1976.12$ )

測定した。これによると，合成ペニシリン剂，セ ファロスポリン剂に耐性であることが特徴として あげられ, ampicillin, sulbenicillin は MIC が $25 \mu \mathrm{g} / \mathrm{ml}$ 以上, cefazolin, cephaloridine も全株 が $100 \mu \mathrm{g} / \mathrm{ml}$ 以上である. kanamycin, gentamicin, dibekacin, amikacin, のアミノグリコシド剂 はすぐれた抗菌力を示し, gentamicin は約 $90 \%$ の株が $3.13 \mu \mathrm{g} / \mathrm{ml}$ 以下の MICを示した.マク ロライド剤のうち lincomycin, clindamycin は抗 菌力が弱いが, erythromycin では大部分の株の MIC が1.56〜 $12.5 \mu \mathrm{g} / \mathrm{ml}$ 以下である.テトラサ イクリン剤は強い抗菌力を示し，とくに minocycline, doxycycline にはすぐれた抗菌力が認め られる. minocycline は99\%の株が $0.2 \mu \mathrm{g} / \mathrm{ml}$ 以 下に分布した。 chloramphenical は抗菌力が弱 いが， colistin には全株が $1.56 \sim 12.5 \mu \mathrm{g} / \mathrm{ml}$ に MICをもち, 抗菌力が強い, nalidixic acid も約 85\%の株の MIC が $1.56 \sim 12.5 \mu \mathrm{g} / \mathrm{ml}$ にありよ い抗菌力を示したが, pipemidic acid, piperami- dic acid はそれほどよい抗菌力を示さない。

このように Ac. calcoaceticus は現在広く頻用 されている合成ペニシリン剂, セファロポリン剂 に耐性である。これは清水 ${ }^{6)}$ も云つているように これらの薬剤の使用状況と本菌感染症の拡大に関 係があることが推定される。抗生剤乱用をさけ， 本菌感染症拡大防止につとめなければならない。

\section{おわりに}

Ac. calcoaceticus による感染について，その 分離例の臨床的背景と本菌の薬剤感受性を中心に 述べた。

Acinetobacter $は$ Ps. aeruginosa, Ps. maltophilia などのブドウ糖非醗酵菌や Serratia, Enterobacter などの腸内細菌とともに感染防御力の低 下した患者の難治感染症の原因菌として注目され てきた。しかし，本菌の病原性に関してはまだ十 分に検討されているとはいい難い. 本菌と感染症 の関連を詳細に追求し, 把握することが今後の課 題であり, 一方, 本菌による感染をいかに防止す 
るかも重要な問題である。

\section{文 献}

1) Lessel, E.F.: International Committee on Nomenclature of Bacteria. Subcommittee on the Taxonomy of Moraxella and Alleid Bacteria. Int. J. Syst. Bacteriol. $21: 313$, 1971.

2) Glew, R.H., et al: Infections with Acinetobacter calcoaceticus (Herella vaginicola): Clinical and Laboratory studies, Medicine, 56 (2) : 79-97, 1977.

3）那須勝 : ブドウ糖非醗酵グラム陰性桿菌群と感
染症, 内科領域の感染症 (1), 最新医学, 32 (11) : 2069-2078, 1977.

斉藤厚 : ブドウ糖非醴酵グラム陰性桿菌群と感 染症, 内科領域の感染症 (2), 最新医学, 32 (11) : 2079-2086, 1977.

4) 熊沢浄一：ブドゥ糖非醗酵グラム陰性桿菌群と 感染症, 尿路感染症, 最新医学, 32(11) : 2107 $-2112,1977$.

5）清水喜八郎：糖非醗酵グラム陰性桿菌感染症一 とくにアンネトバクター感染症について一，日 本レダリ一, 東京, 1977 . 